KEJADIAN 12:1-9

(Abram Dipanggil Allah)

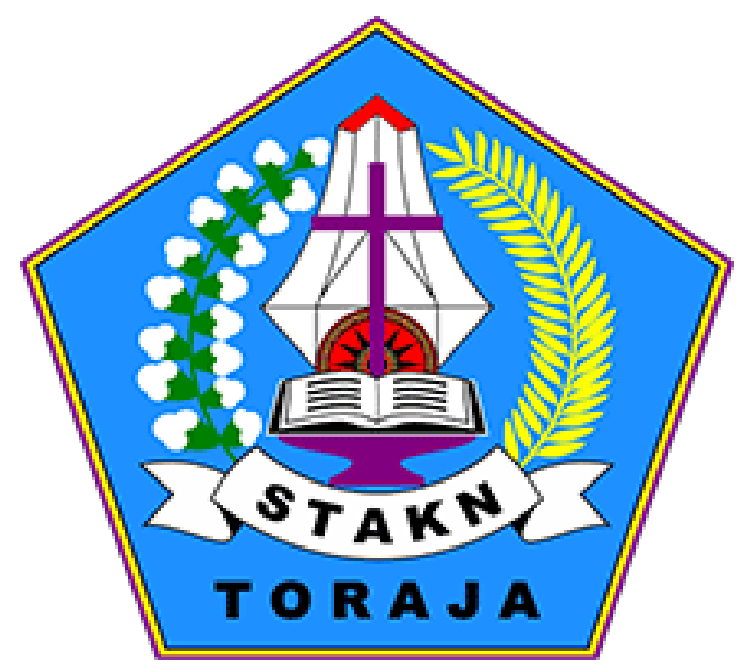

Oleh:

Sriyuni

2020164840

Sekolah Tinggi Agama Kristen Negeri (STAKN) Toraja Tahun Akademik 2019 


\section{KEJADIAN 12:1-9}

\section{(Abram Dipanggil Allah)}

\section{A. LATAR BELAKANG}

Kejadian adalah kitab tentang permulaan. Kelima puluh pasalnya menggambarkan sejarah manusia dari penciptaan sampai Babel (pasal 1-11) dan dari Abraham sampai Yusuf (pasal 12-50). Sebelas pasal pertama memperkenalkan Allah Pencipta dan permulaan kehidupan, dosa, hukuman, keluarga, penyembahan, dan keselamatan. Pasal-pasal selebihnya fokus pada kehidupan empat Bapa iman: Abraham, Ishak, Yakub, dan Yusuf, dan dari merekalah berasal bangsa Israel dan pada akhirnya Juruselamat, Yesus Kristus. ${ }^{1}$ Kejadian ditulis untuk menyajikan permulaan segala sesuatu kecuali Allah. Panggilan Abraham adalah titik paling penting dari kitab ini. Tiga perjanjian yang Allah buat dengan Abraham (negeri, keturunan, dan berkat) adalah dasar rencana keselamatan Allah bagi bumi. ${ }^{2}$

Antara Kejadian 11 (1-11) dan Kejadian 12 ada suatu sela-sela (celah) yang tidak cukup diperhatikan dan dihargai, yakni bahwa Allah menolak, membuang, membiarkan, tidak mengindahkan orang banyak dan keseluruhan manusia lagi, melainkan hanya memperdulikan, memperhatikan, menghiraukan satu orang saja: Abraham. Kejadian 1-11 adalah penuh dengan keseluruhan, keuniversalan, keseduniaan, kemanusiaan. Dalam kejadian 12 telah mulai keistimewaan, kekhususan, perseorangan, partikularismus dari Alkitab. Keselamatan dijanjikan dan dipautkan kepada satu orang, yakni kepada Abraham. Panggilan Allah tidaklah disampaikan kepada keluarga bapa Abraham atau kepada marganya atau sukunya atau bangsanya, melainkan kepada terikat, tersangkut dan terpaut kepada perseorangan (individuasi,

\footnotetext{
${ }^{1}$ Bruce Wilkinson \& Kenneth Boa, Talk Thru the Bible, (Malang: Gandum Mas 2017 ),31

${ }^{2}$ Ibid, 33
} 
individualisme). Bahwa panggilan itu diarahkan, dialamatkan, disampaikan dan dihadapkan kepada Abraham, anak Terah, cucu Nahor, yang "berbangsa" Eber, keturunan Sem, adalah sama sekali secara kebetulan (kontingent). Kenyataan itu bukanlah sekali-kali dipersiapkan atau didasarkan atas sesuatu dalam kehidupan Abraham sendiri, melainkan adalah berdasarkan kemerdekaan dan pemilihan oleh Allah, Tuhan semeta alam, dan ini akan tetap tinggal (merupakan) suatu rahasia yang tak dapat dipahami manusia. ${ }^{3}$

Kekekalan menyentuh sejarah, Allah berjumpa dengan manusia, surga bertalian dengan bumi, hanyalah di dalam (dengan perantaraan) orang yang satu ini: Abraham. Tetapi Abraham adalah tokoh sejarah umum. Ia berasal dari Haran (dan sebelumnya dari UrKasdim) di Asia -Barat. Ia disebutkan di dalam sejarah umum, yaitu dalam millennium ke-II sM. Keturunannya, bangsa Israel, adalah dikenal sebagai negeri di muka bumi ini, dari kira-kira 1200 sM. Sampai dengan tahun 587 sM di Palestina (dan kembali sejak tahun 1948 sM di atas jembatan Asia-Afrika). ${ }^{4}$

Keselamatan yang dari Allah tidaklah terbatas kepada Abraham dan keturunannya saja, melainkan meliputi, merangkumi, melingkungi dan melingkupi segala kaum manusia. Dalam seluruh sejarah keselamatan itu Abraham tidaklah lebih dan tidak kurang daripada perkakas dan alat Allah untuk menandakan dan menunjukkan keselamatan yang dari Allah itu di hadapan segala bangsa. Abraham adalah pelopor, hulubalang, perintis, pandu, pendekar, perambah (peretas) jalan kemanusiaan yang baru, manusianya Allah. 5

\footnotetext{
${ }^{3}$ Walter Lempp, Tafsiran Alkitab: Kitab kejadian 5:1-12:3 (Jakarta: BPK Gunung Mulia, 2003), 195-196

${ }^{4}$ Ibid.

${ }^{5}$ Ibid, 197.
} 


\section{B. STRUKTUR}

Pemanggilan Abram dari Urkasdim dan penggenapan janji tentang satu bangsa yang besar telah digenapinya. ${ }^{6}$ Isi dari pemanggilan Abram oleh Allah terdiri atas 3 bagian, yaitu panggilan dan janji Allah kepada Abram (12:1-3), Abram memulai perjalanannya sesuai dengan firman Tuhan (12:4-6), dan Tuhan menampakkan diri kepada Abram (12:7-9). Dibagian awal (12:1-3) Allah berfirman kepada Abram untuk pergi dari negerinya menuju ke negeri yang akan ditunjukkan Allah kepadanya (12:1). Selain itu Allah juga menjanjikan keturunan, kemasyhuran dan janji berkat bagi Abraham (12:2-3).

Pada bagian yang kedua, (12:4-6) Abram memulai perjalanannya sesuai dengan Firman Tuhan. Abram bersama Sarai, Lot dan harta benda dan orang-orangnya meninggalkan Haran menuju Kanaan (12:4-5). Abram menyusuri daerah itu hingga tiba di tempat yang bernama More (12:6).

Pada bagian terakhir, (12:7-9) Tuhan menampakkan diri kepada Abram. Tuhan menjanjikan memberikan negeri itu kepada keturunannya, Abram mendirikan bagi Tuhan di tempat itu kemudian berpindah ke pegunungan sebelah timur Betel, mendirikan mezbah bagi Tuhan dan memanggil nama Tuhan (12:7-8). Sesudah itu Abram berangkat dan makin jauh ia berjalan ke Tanah Negeb (12:9). Adapun kerangka Kejadian 12:1-9 adalah sebagai berikut:

\section{Panggilan dan janji Allah kepada Abram (12:1-3)}

a. Firman Tuhan kepada Abram untuk pergi dari negerinya menuju ke negeri yang akan ditunjukkan Tuhan kepadanya. (12:1)

\footnotetext{
${ }^{6}$ Ponco Mujiono Basuki. “pemahaman Kata GO'EL dalam kitab Rut.” Journal Kerusso 3.2 (2018):20-24
} 
b. Janji keturunan, kemasyhuran, dan janji berkat bagi Abram. $(12: 2-3)$

\section{Abram memulai perjalanannya sesuai dengan Firman Tuhan} (12:4-6)

a. Abram bersama Sarai, Lot dan harta bendanya meninggalkan Haran menuju Kanaan. (12:4-5)

b. Abram menyusuri Kanaan dan tiba di More. (12:6)

\section{Tuhan menampakkan diri kepada Abram 12:7-9}

a. Janji untuk keturunan Abram. Abram mendirikan mezbah bagi Tuhan (12:7-8)

b. Abram menuju Tanah Negeb (12:9)

\section{ANALISIS TAFSIR}

\section{Panggilan dan janji Allah kepada Abram (12:1-3)}

Mengapa justru Abram yang dipilih untuk disuruh dan diberi janji berkat? Jawaban atas pertanyaan ini adalah contoh dari kebebasan TUHAN siapa yang akan dipilih-Nya guna melakukan rencana-Nya. Rencana Allah untuk menyelamatkan umat Allah tampak dari pemanggilan Abram. Dari Abram diteruskan ke Ishak yaitu anaknya yang lahir dari Sara untuk menggenapi keselamatan umat manusia. ${ }^{7}$ Abram, kepala rumah tangga yang malang dan gagal dialah yang dipilih oleh TUHAN. Tak ada sesuatu yang dapat diandalkan dari Abram-menurut kacamata masyarakat sekitarnya. Tapi, orang yang tak terandalkan inilah yang justru diandalkan oleh TUHAN, untuk melaksanakan perintah dan rencana-Nya. ${ }^{8}$

Cara yang tepat yang digunakan Allah untuk berhubungan dengan Abraham tidak diperlihatkan; ayat tersebut hanya berbunyi, “Berfirmanlah Tuhan”. Mungkin sekali panggilan ini disertai dengan

\footnotetext{
${ }^{7}$ Antonius Isharjono. Menerapkan pola pendidikan rohani anak berkebutuhan khusus (Attention Deficit or Hyperactivity Disorder). JURNAL TERUNA BHAKTI, 2.1 (2019):37-48

${ }^{8}$ Nico Gara, Menafsir Alkitab Secara Praktis, (Jakarta: BPK Gunung Mulia,),45
} 
penampakan Tuhan (bnd. Kis. 7:2). Mula-mula Allah memanggil Abraham di Ur, dan Allah mengulangi panggilan itu ketika Abraham berada di Haran (Kej. 12:1-3). Alkitab Authorized Version menunjukkan hal ini dalam bentuk waktu lampau yang sempurna "had said (telah berfirman)." Meskipun teks Ibrani hanya menggunakan bentuk imperfek dengan waw yang konsekutif, rupanya secara gramatikal terjemahan bentuk waktu lampau yang sempurna itu diperbolehkan dan juga lebih baik. Beberapa penafsir mencela Abraham karena tanggapannya yang lambat, karena kurang peka terhadap pesan Allah. Akan tetapi, celaan ini agaknya keras sekaligus tidak akurat. Kelambatan ini mungkin sekali adalah akibat dari berbagai pertimbangan pribadi atau keluarga, sepert usia Terah yang sudah tua. Mungkin Abraham sedang menunggu saat yang tepat untuk memutuskan hubungan keluarganya, dan ketika saat itu tiba, Allah mengulang panggilan itu. Perlu ditekankan juga bahwa Allah memanggil, atau memilih, Abraham bukan karena sesuatu kebaikan di pihak Abraham. Sebaliknya, latar belakang Abraham adalah polities, dan apa pun yang dia peroleh dari tangan Allah merupakan ungkapan kasih karunia yang murni. Apa yang dikatakan tentang Abraham dapat dikatakan juga tentang setiap orang yang datang kepada Tuhan karena iman. Yang patut kita terima-hukuman-dengan murah hati ditahan-Nya, dan hal yang tidak patut kita terima-berkat pengampunan dengan cuma-cuma diberikan-Nya. Berulang-ulang hal ini menyebabkan para penulis Kitab Suci menaikkan pujji-pujian bagi Allah. ${ }^{9}$

a. Firman Tuhan kepada Abram untuk pergi dari negerinya menuju ke negeri yang akan ditunjukkan Tuhan kepadanya.

(12:1). Tuhan adalah pokok kalimat pertama: Dalam hati-Nya,

\footnotetext{
${ }^{9}$ John J. Davis, Eksposisi Kitab Kejadian. Suatu telaah dalam Kitab Kejadian, (Malang: Gandum Mas, 2001), 177-178
} 
dalam kasih-Nya, dalam rencana-Nya tersembunyi dan berpangkal sejarah yang dimulai di sini. Tidak dapat ditanyakan apa alsanalasan kemauan-Nya. Berfirmanlah: seluruh sejarah yang berikut (yakni kehidupan Abraham, Ishak dan Yakub, adanya Israel dan adanya gereja Yesus Kristus) adalah dijadikan dan di “ada”kan oleh Firman Allah.

Kepada Abram : Allah menegur (menyapa, menyampaikan firman-Nya kepada) manusia perseorangan: bukanlah menuju individualismus, tetapi untuk inviduasi ( menjadi keoknuman dan kepribadian yang bebas dan bertanggungjawab, yang memberi jawab kepada Allah) mmenuju persekutuan orang-orang yang melakukan kemauan Allah. Kepada Abraham, anak Terah, orang Eber, keturunan Sem, di kota Haran di Asia Barat, pada masa parohan pertama dan millennium ke-II s.M., Allah menyampaikan firman-Nya dan perjanjian-Nya bukan kepada segala bangsa (Mazmur 147:19-20). Kalau kita mau berjumpa dengan perantaraan Abraham maka Allah mengadakan jam-bicara dengan kita manusia, dan kecuali dengan perantaraannya tidak ada yang lain.

Pergilah a) dari negerimu, b) dari sanak-saudaramu, dan c) dari rumah bapamu. 10 Dengan kata lain, Abraham harus meninggalkan sama sekali semua yang berarti baginya, seorang penduduk Mesopotamia. Imannya tidak buta karena ia mengetahui kuasa Allah dan memiliki janji-Nya akan menunjukkan kepadanya suatu negeri yang baru. Tentu saja, Allah jarang menuntut korban perseorangan seseorang tanpa memberi imbangan berkat-berkat yang bahkan lebih besar. Perginya Abraham dari Mesopotamia dan rumah ayahnya mungkin berarti ia kehilangan warisannya, tetapi

\footnotetext{
${ }^{10}$ Walter Lempp, Tafsiran Alkitab: Kitab kejadian 5:1-12:3 (Jakarta: BPK Gunung Mulia, 2003), 198-199
} 
betapa jauh lebih besarnya hal-hal yang dijanjikan Allah. Memang, ia akan meninggalkan suatu negeri dengan kota-kota besar yang kaya akan barang materi, tetapi Tuhan menjanjikan suatu warisan baru yang akan meliputi suatu negeri yang lain (ayat 1 bnd. Kej. 13:15,17 )11. Dari negerimu (me'artseka, erets): Itulah pengaruh dan kepentingan daya dan kuasa negeri asal, tanah air, tanah tumpah darah. Alangkah besarnya dan kuatnya pengaruh tersebut pada masing-masing kita. tiap-tiap negeri, tiap-tiap tanah, tiap-tiap daerah mempunyai (atau lebih baik "dipunyai") dewa-dewa, citacita, adat-istiadat, filsafat dan ekonomi, yaitu sifat alamiah, watak dan kecenderungannya sendiri. Dengan tidak insaf masing-masing orang dicap, ditempa, ditera dan dimeteraikan sampai suatu tingkat yang tidak terpikirkan.

Dari sanak saudaramu (moledet) menguraikan lingkungan manusia yang sedarah-edaging,semarga, semoyang, sekerabat, sekaum-keluarga, sesanak-saudara. Abraham dipanggil meninggalak sanaknya, yaitu menyangkal, tidak mendengarkan dan tidak mematuhi suara darah, tetapi untuk mematuhi suara Allah. Dari rumah bapamu (beyt abika) adalah sebagian dari "sanak saudara" (moledet = misypakha). (Menurut huruf, kata itu berarti "rumah-tangga".) Dalam "rumah bapa" termasuk seorang suami, isteri, anak-anaknya yang perempuan (yang masih dara). Ke negeri yang akan Kutunjukkan kepadamu. Sebagai pengganti negeri asalnya yang harus ditinggalkan Abraham, maka Allah menjanjikan kepadanya suatu negeri yang baru. Tujuan dan akhir perjalanan itu tersembunyi dalam perjanjian / janji Allah: Abraham tidak diberitahu ke mana arah jalannya. Ia dipanggil dari suatu kehidupan, yang terpaksa oleh jalan masa lampau, menuju suatu kehidupan baru, yang dibimbing oleh kemerdekaan dan kesetiaan

\footnotetext{
${ }^{11}$ John J. Davis, Eksposisi Kitab Kejadian. Suatu Telaah dalam Kitab Kejadian , (Malang: Gandum Mas, 2001)178
} 
dan kasih Allah. Suatu pengembaraan, penjelajahanm pengalaman dan petualangan yang bukan main, tetapi petualang yang tertuju. ${ }^{12}$

b. Janji keturunan, kemasyhuran, dan janji berkat bagi Abram. $(12: 2-3)$

Ia akan menjadi bangsa yang besar. Orang yang isterinya mandul, yang tidak punya harapan lagi akan keturunan, dijanjikan keturunan yang besar. Yang ditinggalkannya (sanak-saudaranya) diberi Allah kepadanya secara baru (keturunannya). Kebesaran yang dirindukan masyarakat Babel akan diberikan kepada Abraham. Dalam Perjanjian Lama isi berkat Allah sangat dekat berhubungan dengan keturunan. Allah memberkati Abraham (=memberikan berkat). Berkat dalam Perjanjian Lama berarti bermacam-macam pertambahan kehidupan, pergandaan penghidupan; barangkali kata berkat yang pertama dalam ayat 2 dapat dipahamkan mengenai harta benda Abraham. Tetapi kata berkat yang kedua "dan engkau akan menjadi berkat" tak hanya menerima berkat tetapi juga menjadi berkat. Nama Abraham menjadi masyhur dibuat Allah: Ia menjadi seorang yang kenamaan, seorang yang ternama, seorang yang berpengaruh pada banyak orang.

Aku akan memberkati orang-orang yang memberkati engkau: di dalam Abraham segala macam manusia akan mengenali dan mengakui berkat dan keselamatan yang dari Allah, Tuhan semesta alam. Dan mengutuk orang-orang yang mengutuk engkau: orangorang yang mengutuk Abraham akan dikutuk oleh Allah. Dan olehmu semua kaum di muka bumi akan mendapat berkat. Itulah kemauan Allah. Alangkah besar pemanggilan Abraham, bukan

\footnotetext{
${ }^{12}$ Walter Lempp, Tafsiran Alkitab: Kitab kejadian 5:1-12:3 (Jakarta: BPK Gunung Mulia, 2003), 200-201
} 
main tingginya pangkatnya! Tak terkatakan pentingnya pemanggilan orang yang satu ini. ${ }^{13}$

\section{Abram memulai perjalanannya sesuai dengan Firman Tuhan} (12:4-6)

Abram tidak tinggal diam dengan panggilan Tuhan ia melakukan sebagaimana perintah Tuhan. Sebagai jawaban atas panggilan dan janji-janji Allah, dalam usia tujuh puluh lima tahun Abraham meninggalkan Tanah Mesopotamia. Abram berangkat menurut panggilan Yahwe, tetapi janji-Nya tidak digenapi dengan segera. Abram tidak segera menjadi seorang tuan besar, melainkan menjadi seorang musafir, seorang pengembara, pengungsi seorang asing di tanah yang telah disumpah-janjikan oleh Yahweh kepadanya. Ia berpindah dari tempat satu ke tempat yang lain. Penggenapan janji Allah itu masih ditunda. Ia belum dapat melihat penggenapan janji Allah itu, melainkan harus percaya. ${ }^{14}$

\section{a. Abram bersama Sarai, Lot dan harta bendanya meninggalkan}

Haran menuju Kanaan. (12:4-5) . Lalu pergilah Abram seperti yang difirmankan TUHAN kepadanya: Firman dan Panggilan Allah yang dituruti oleh segala kuasa semesta alam, tetapi yang diabaikan dan ditolak oleh manusia untuk pertama kalinya dipatuhi dan ditaati oleh seorang manusia dengan segera dan seketika itu juga. Abraham mematuhi dan mentaati panggilan Allah tanpa bertanya, tanpa menunggu atau menunda, tanpa jaminan, disamping janji Allah sendiri. Abraham bukanlah pelancong atau wisatawan, melainkan langkahnya yang luarbiasa itu disebabkan oleh desakan suara Allah; perjalanannya adalah perjalanan dinas. Dengan sangat sederhana dilukiskan kepatuhan

\footnotetext{
${ }^{13}$ Ibid, 202-203

${ }^{14}$ Walter Lempp, Tafsiran Alkitab: Kitab kejadian 12:4-25:18, (Jakarta: BPK Gunung Mulia, 2003), 2823
} 
Abraham: "Abraham pergi." Kepatuhan Abraham adalah kepatuhan terhadap Allah, bukan terhadap manusia.

Dan Lot pun ikut bersama-sama dengan dia, menurut sumber Y Lot tidak dipanggil Allah, ia turut dalam berkat Allah, tetapi hanya sebagai pengikut saja. Lot mewakili generasi yang malang. Sarai dan orang-orang yang diperoleh mereka di Haran mewakili seluruh anggota rumah tangga. Iman, pengaharapan, serta kaih ternyata bukan hanya menjadi milik pribadi, tetapi juga menjadi bagian orang-orang serumah. Janji Tuhan berlaku bagi isi rumah tangga dari orang beriman. Tapi hal itu tidak mudah, sebagaimana Abram yang harus menempuh perjalanan yang jauh ke tempat yang belum passti dengan membawa beban (harta benda) dan tanggungjawab (Sara dan Lot). 15

Tanah Kanaan adalah tanah yang dijanjikan Allah, meskipun hal itu tidak diucapkan dengan kata yang jelas. Tetapi para pembaca diharap mengetahuinya menurut maksud penulis.

b. Abram menyusuri Kanaan dan tiba di More. (12:6). Abram tidak dapat langsung menduduki tanah yang dijanjikan kepadannya. Selaku seorang asing atau penumpang Abram hanya dapat melalui, melewati, dan mengelilingi tanah yang dijanjikan kepadanya itu. Tanah itu bukan kosong, sehingga ia hanya dapat mengisinya. Sampai ke suatu tempat di Sikhem, yaitu pohon tarbantin di More. Istilah Ibrani untuk "tempat" (maqom, bhs. Indonesia "makam") seringkali di dalam Alkitab dipergunakan dalam arti "tempat-suci”, tempat keramat, pusat-sembahyang. Kita mnegetahui, bahwa Sikhem (artinya: bahu, tengkuk, kuduk) memegang peranan yang luar biasa selaku pusat sembahyang dan sebagai tempat perkumpulan kedua belas suku itu yang bersatu dalam persekutuan ibadat (Amphiktyonie). Pohon tarbantin di

\footnotetext{
${ }^{15}$ Nico Gara, Menafsir Alkitab Secara Praktis, (Jakarta: BPK Gunung Mulia,),46
} 
More: "pohon tarbantin" seringkali juga diterjemahkan dengan "pohon-ek" pohon suci. More artinya "petunjuk" kadang-kadang dipakai dalam arti "guru" (Yes. 30:20; Ayub 36:22; Amsal 5:13). Barangkali dapat dipahamkan, bahwa di bawah pohon suci tersebut pada mulanya diberikan wahyu dan ramalan (petunjuk). Tetapi, More sekarang telah menjadi nama tempat suci sekeliling pohon itu. Dengan penjelasan-penjelasan di atas ini teranglah bahwa Abraham pergi kepada salah satu tempat-suci di daerah suku Utara yang terkuat, yakni Manaye, yang termasuk keturunan atau keluarga Yusuf. ${ }^{16}$

3. Tuhan menampakkan diri kepada Abram 12:7-9 Menandai Abraham sebagai pendiri ibadat di Sikhem, sebab ia menerima wahyu (penyataan) Yahwe di sana. Ketika itu TUHAN menampakkan diri kepada Abram: Itulah berita wahyu (theophani) biasa yang mengesahkan kesucian dan ketulenan salah satu tempat suci. Adalah sangat penting bahwa wahyu itu diringi oleh perkataan / firman:...Aku akan memberikan negeri ini kepada keturunanmu.

a. Janji untuk keturunan Abram. Abram mendirikan mezbah bagi Tuhan (12:7-8). Penyataan diri Yahwe Israel bukanlah pembukaan layar di depan salah satu tugu, melainkan adalah penyataan diri denga perantaraan firman yang akan berlangsung dan terwujud di dalam sejarah. Isi firman itu adalah janji tentang tanah dan keturunan, seperti yang berulang kali diucapkan, tetapi yang sekali ini berupa sebagai berikut: bukan kepada Abram sendiri saja janji itu akan ditepati, melainkan kepada keturunanNya. Janji Allah melengkapi hidup perseorangan . abram sendiri tidak akan melihat penggenapan janji itu. Yang Allah mulai dari satu orang dimaksudkan dan direncanaakan untuk banyak orang. Bahkan keturunan Abram bukan hanya akan melihat tanah itu,

\footnotetext{
${ }^{16}$ Walter Lempp, Tafsiran Alkitab: Kitab kejadian 12:4-25:18, (Jakarta: BPK Gunung Mulia, 2003), $28 \& 29$
} 
melainkan Allah akan memberikan tanah itu kepada mereka sebagai milik pusaka. Maka didirikannya di situ mezbah bagi TUHAN yang telah menampakkan diri kepadanya. Penyataan diri Allah merupakan dasar dari dan mengakibatkan Ibadat / Kebaktian. Terhadap penyataan diri Allah itu, Abraham hanya dapat menyerahkan diri kepada Allah. Pembangunan mezbah adalah tanda penyerahan diri atau kebaktian Abraham kepada Allah yang telah memperkenalkan diri kepadanya itu. Bersama ini Abraham mendirikan salah satu tanda- nampak dari kepercayaannya yang tidak nampak. ${ }^{17}$

Dari sini Abraham mengadakan perjalanan ke Betel, dua puluh mil lebih jauh ke arah selatan, memasang kemahnya di atas puncak bukit antada Betel dan $\mathrm{Ai}$, sekali lagi ia mendirikan mezbah bagi Tuhan, dan memanggila nama-Nya (ayat 8). Sifat keberadaan Abraham di negeri itu dilukiskan dengan baik sekali dalam dua kata kerja memasang dan mendirikan. Ia memasang sebuah kemah, bangunan yang sementara, untuk kenyamanan dirinya . Ia mendirikan sebuah mezbah, bangunan yang permanen untuk menyembah Allah. Tidak ada tanda kekayaan atau martabatnya yang ditinggalkan Abram di Kanaan, hanya mezbahmezbah yang telah dibangunnya untuk menyembah Allahnya. ${ }^{18}$ Lalu ia mendiri di situ mezbah bagi TUHAN dan memanggil nama Tuhan: mendirikan mezbah berarti memulai ibadat di muka umum. "Memanggil nama Tuhan ". Istilah itu haruslah dimengerti sebagai doa kepada Allah, berseru kepada Allah dengan memakai nama-Nya. Memanggil Yahweh dengan perantaraan nama-Nya menyeruh atau mengajak Allah datang dengan menyerukan namaNya. Pengertian tersebut diteguhkan lagi oleh nats-nats di mana

\footnotetext{
${ }^{17}$ Ibid, 30 .

${ }^{18}$ John J. Davis, Eksposisi Kitab Kejadian. Suatu Telaah dalam Kitab Kejadian, (Malang: Gandum Mas, 2001), 184
} 
Allah memanggil manusia dengan namanya. "memanggil dengan nama" hampir menerima arti "memilih", "mengerahkan ", "memperkerjakan". Tetapi istilah qara'be syem Yhwh itu dipergunakan juga untuk penyataan Allah di dalam Kel. 33:19 dan Kel. 34:5. Ada juga beberapa nats, di man istilah "memanggil nama Tuhan" itu sejajar dengan "mengucapkan syukur", "mengatakan terima kasih", "mengakui".19

b. Abram menuju Tanah Negeb (12:9). Dari Betel dan Ai Abram pergi ke selatan Negeb. Tanah Negeb dalam wilayah ini umumnya dianggap sebagai wilayah di sebelah barat dan barat daya Laut Mati. Wilayah ini sekarang sangat kering dan tandus, tetapi surve-survei arkeologis yang dilakukan Glueck di sana menunjukkan bahwa dahulu banyak tersebar di mana-mana di wilayah di antara Palestina dan Mesir. Di tanah ini Abram dan orang-orangnya tinggal dan mendapatkan mata pencaharian untuk beberapa kurun waktu yang cukup lama. Tidak diterangkan di dalam teks tersebut alasan Abraham pergi kea rah selatan menuju Negeb; barangkali kelaparan yang disebut dalam ayat 10 telah mulai. ${ }^{20}$

\section{IMPLIKASI}

a. Pengajaran mengenai kedaulatan Tuhan.

Berdasarkan apa kata Tuhan. Firman Tuhan kepada Abram : "pergilh dari negerimu..." (ayat 1) memberikan pandangan teologi bahwa Tuhan berkuasa memilih dan memakai Abram sebagai alatNya. "ke negeri yang akan Kutunjukkan kepadamu" (ayat 1), memberikan pandangan teologi yaitu bahwa Tuhan menjanjikan

\footnotetext{
${ }^{19}$ Walter Lempp, Tafsiran Alkitab: Kitab kejadian 12:4-25:18, (Jakarta: BPK Gunung Mulia, 2003), 31\&32

${ }^{20}$ Ibid, $186 \& 187$
} 
suatu negeri yang baru bagi Abram setelah ia pergi / keluar dari negerinya.

Janji Tuhan kepada Abram, antara lain membuat ia menjadi bangsa yang besar, membuat namanya masyur, memberkatinya bahkan menjadikan Abram sebagai berkat (ayat 2), memberikan perspektif bahwa Tuhan adalah sumber segala sesuatu; kesabaran, berkat (keturunan), kemasyhuran, serta pemulihan penyelamatan menjadi pribadi yang baru bagi Abram.

Firman Tuhan kepada Abram: "Aku akan memberikan negeri ini kepada keturunanmu" (ayat 7) menandakan bahwa Tuhan adalah pemilik sah dari negeri / tanah itu (Kanaan).

b. Pengajaran mengenai maksud / kehendak Tuhan

Dengan melihat perintah Tuhan kepada Abram untuk pergi dari negerinya ke negeri yang akan ditujukannya (Kanaan) seakan memberikan pandangan tentang maksud Tuhan yaitu supaya Abram membawa berkat Allah kepada semua negeri dan tanah yang dilewatinya dan kepada segala kaum dan bangsa yang dijumpainya. Untuk itu berdasarkan maksud ini memberikan ajaran bahwa berkat yang dari Allah tidaklah terbatas tapi berifat universal.

Berdasarkan kenyataan bahwa Abram berjalan sampai ke suatu tempat dekat Sikhem yakni pohon tarbantin di More yang pada awalnya adalah "tempat suci", tempat keramat, pusat sembahyang, bahkan mendirikan mezbah yang pada dasarnya adalah tempat orang Kanaan mempersembahkan korban yang berdarah kepada dewa Baal, dan di tempat itu pula Allah menempatkan diri melalui Roh dan berfirman kepada Abram memberikan ajaran kepada kita bahwa kehadiran Allah dapat dinyatakan dimana saja, meskipun pada awalnya itu adalah tempat persembahan korban-korban kepada Baal. 
c. Pengajaran mengenai konsekuensi

Melihat panggilan Tuhan kepada Abram yang di dalamnya juga berisikan janji-janji berkat, memberikan pengajaran bagi kita bahwa ada konsekuensi dari setiap kepatuhan akan perintah Tuhan yakni Abram akan diberkati apabila ia menjalankan setiap perintah Tuhan bahkan lewat dia semua bangsa akan diberkati namun apabila ia tidak menjalankan akan perintah Tuhan maka sebaliknya akan dikutuk dan tidak akan diberkati. Jadi, dapat ditemukan sebuah pemahaman teologi yakni teologi pemanggilan.

\section{KEPUSTAKAAN}

Basuki, Ponco Mujiono. "pemahaman Kata GO’EL dalam kitab Rut." Journal Kerusso 3.2 (2018):20-24

Boa, Kenneth \&Bruce Wilkinson Talk Thru the Bible.(Malang: Gandum Mas. 2017.

Davis, John J. Eksposisi Kitab Kejadian. Suatu telaah dalam Kitab Kejadian.Malang: Gandum Mas. 2001.

Gara, Nico. Menafsir Alkitab Secara Praktis. Jakarta: BPK Gunung Mulia.

Gertz, Jan Christian. Purwa Pustaka. Eksplorasi ke dalam kitab-kitab perjanjian lama dan deutrokanonika. Jakarta: BPK Gunung Mulia. 2017.

Green, Denis. Pembimbing pada Pengenalan Perjanjian Lama. Malang: Gandum Mas. 2012

Isharjono, Antonius. Menerapkan pola pendidikan rohani anak berkebutuhan khusus (Attention Deficit or Hyperactivity Disorder). JURNAL TERUNA BHAKTI, 2.1 (2019):37-48 
Lempp, Walter. Tafsiran Alkitab: Kitab kejadian 5:1-12:3 . .Jakarta: BPK Gunung Mulia. 2003.

Lempp,Walter. Tafsiran Alkitab: Kitab kejadian 12:4-25:18. Jakarta: BPK Gunung Mulia, 2003. 